\title{
Effect of Progressive Muscle Relaxation on Sleep Quality and Side Effects of Chemotherapy in Children with Cancer: Randomized Clinical Trial
}

\author{
Erna Sulistyawati ${ }^{1}$ (D) , Allenidekania Allenidekania ${ }^{2}$ (D) Dewi Gayatri ${ }^{2 *}$ (i) \\ ${ }^{1}$ Program of Nursing Science, Universitas Muhammadiyah Semarang, Semarang, Indonesia; ${ }^{2}$ Department of Basic Nursing \\ Science, Faculty of Nursing, Universitas Indonesia, Depok, Indonesia
}

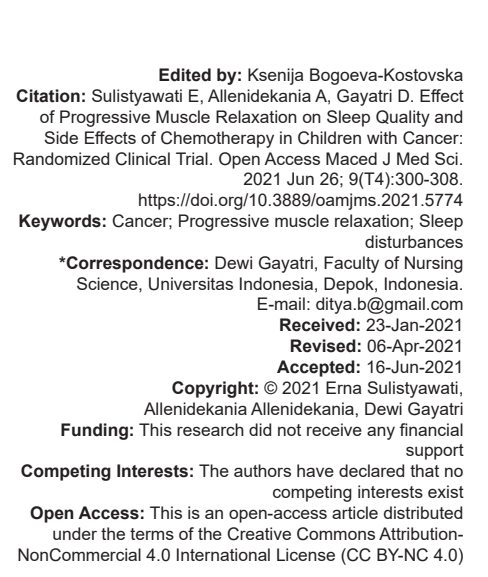

Abstract

BACKGROUND: Sleep disturbance affects quality of life in children receiving chemotherapy.

AIM: The aim of this study was to identify the effect of progressive muscle relaxation on the sleep quality and side effects of chemotherapy in children with cancer.

METHODS: This study used randomized clinical trial with single blind method, where 30 children were allocated randomly to the control group and intervention group. The intervention group received progressive muscle relaxation twice a day, in the morning and evening, 15 min each session for 7 days. Control group received routine nursing care. RESULTS: The study concluded there was no significant difference in the two groups on fatigue and pain. However progressive muscle relaxation had significant relation to decreased sleep quality score.

CONCLUSION: Relaxation therapy, particularly progressive muscle relaxation, may be one of the nursing cares to improve sleep quality and reduce the side effects of chemotherapy in children with cancer.

\section{Introduction}

Cancer is a disease caused by a group of exposed cells that could spread to other healthy organs. Cancer in children is different than in adult as cancer in adult is preventable while the one in children is not [1] Cancer cell in children originated from non-epithelial tissue thus the cell growth is faster [2], [3]. The common types of cancer in children are leukemia, lymphoma, tumor in the central nervous system neuroblastoma, and retinoblastoma [4].

International Agency for Research on Cancer in 2008 estimated there were 160,000 cancer in children cases globally with 90,000 death by cancer every year. National Cancer Institute in 2015 reported that there was approximately 10,380 cancer in children cases in the United States of America with 1000 death by cancer [5]. In 2014, population in Indonesia reached 247 million according to the World Health Organization with $40-50 \%$ were children aged $0-14$ years. About $3-10 \%$ of Indonesian population were children with cancer and the mortality rate was 4-5\% [6].
Cancer treatments cause pain for children; therefore, it is likely to make them feel depressed as they have life-threatening disease with continuous painful therapies [2], [3]. Chemotherapy is an effective therapy for children with cancer. It is used to treat cancer that cannot be treated with surgery or radiation therapy. It is able to kill cancer cells and prevent metastasis [7], [8]. Chemotherapy works by destroying cancer cells, but it can also affect normal cells by inhibiting their performance [9]. Common condition experienced by children with cancer in their chemotherapy is fatigue, mucositis, nausea, pain, sleep disturbance, depression, anxiety, mood swing, and behavioral changes [10], [11], [12].

Sleep disturbance often not realized by children, their parents, or health-care professionals. In general, there percentage of sleep disturbance in children reaches $30 \%$ and it increases in children with chronic disease, such as cancer [13]. Sleep disturbance in children with cancer could be influenced by stress or other factors related with their disease. These factors can be classified as direct and indirect factors. Direct factors are brain injury due to brain tumor, hydrocephalus, surgical procedures, and cranial 
radiation therapy, while chemotherapy is considered as indirect factor [9]. Chemotherapy's side effects that could cause sleep disturbance are fatigue, nausea, and pain [14], [15].

Pain is one of the common symptoms experienced by patient of acute illness. Tumor growth causes pain as it compresses nerves, bones, and other surrounding organs. Pain could influence sleep quality, and sleep itself affects perception and toleration of pain on the other hand. Other causes of pain are chemotherapy side effects, lumbar puncture, and bone marrow aspiration [16]. Pain affects subjective sleep parameter of an individual, while indirectly influences fatigue [14].

A phenomenology study of adolescents with cancer treated by chemotherapy confirms the relation of fatigue to sleep disturbance. Fatigue mainly occurs as a consequence of chemotherapy side effects, which has symptoms of physical discomfort such as exhaustion, aches, limp, and others [17]. Other study conducted by Sahin and Dayapoglu regarding fatigue and sleep quality of chronic obstructive pulmonary disease (COPD) patients shows that fatigue level is inversely proportional to sleep quality [18].

Common sleep problems include difficulty to sleep, increased frequency of waking up in the middle of the night, and excessive drowsiness during the day [17]. In general, sleep disturbance affects daily activities such as decreased productivity, concentration problems, behavior changes, limp, lack of enthusiasm, unconcerned of his surroundings, problems in social interaction, and inability to recover energy after doing activities [18], [19], [20]. Sleep disturbance also influences behavior and cognitive function development of children thus affecting their study achievement [19], [21]. Sleep disturbance in children with cancer affects their quality of life, which causes their inability to cope with stress, anxiety, pain, illness, and depression that contributed to the sustainability of their chemotherapy program [9], [13].

Treatment of chemotherapy side effects improves children's internal strength and supports them in coping with their illness. Relaxation technique is a complementary therapy used to treat chemotherapy side effects [22]. Srilekha, Soumendra, and Chattopadhyay state that progressive muscle relaxation performed in three 15 min sessions weekly for two consecutive months improves concentration and reduces anxiety in children aged 9-12 years in India and Bangladesh [23]. This result is in line with Lee, Bhattacharya, Sohn, and Verres study, where progressive muscle relaxation provides relaxing effect, reduces anxiety, and improves physical and psychological patient of gynecologic cancer receiving chemotherapy by increasing posterior theta activities (3.5-7.5 Hz) and reducing midfrontal beta-2 band (20-29.5 Hz) in the later part of therapy [24].
Progressive muscle relaxation also improves breast and prostate quality of life of cancer patients receiving chemotherapy. The result of saliva testing of patients treated with four sessions of progressive muscle relaxation and guided imagery shows the decrease of amylase level. $\alpha$-amylase is one of the enzymes secreted by salivary glands as a response on sympathetic stimulation. Stress response of an individual influenced by his hypothalamuspituitary-adrenocortical axis (HPA) and sympathoadrenomedullary (SAM) systems. Amylase and cortisol are indexes of HPA and SAM, which means that the decrease of amylase level is related to the decrease in individual's stress response. Other study concludes that progressive muscle relaxation and guided imagery are effective in reducing level of depression, pain, and anxiety in breast and prostate cancer patients [25].

Sahin and Dayapoglu explain that progressive muscle relaxation improves sleep quality of COPD patients. Their study used $70 \mathrm{~min}$ video as medium to explain progressive muscle relaxation, which was classified to three parts. The first part explained definition and objectives of progressive muscle relaxation for $10 \mathrm{~min}$, while $30 \mathrm{~min}$ second part explained the relaxation techniques, and finally the third part only filled with relaxation music for $30 \mathrm{~min}$. This study also used booklet to explain progressive muscle relaxation techniques. This intervention was conducted once per day for 6 weeks [18]

Progressive muscle relaxation is a nonpharmacological therapy that is inexpensive, easy, and safe. Therefore, it is necessary to investigate the relation of progressive muscle relaxation to sleep quality and chemotherapy side effects in children with cancer. The effects of sleep disturbance often unrealized by children, parents, and health-care professionals have been studied extensively. However, studies regarding sleep disturbance in children with cancer receiving chemotherapy are limited, thus sleep disturbance management is not optimal. The aim of this study was to identify the effect of progressive muscle relaxation on sleep quality and chemotherapy side effects in children with cancer.

\section{Methods}

This study used clinical trials method where authors treated intervention group to be compared with control group, where participants were classified into groups randomly. This study used single blind randomized clinical trial. Assessment was conducted with single blind where research subjects did not know which group they were [26], [27]. In this study, progressive muscle relaxation was performed in intervention group, but not in control group. Effectiveness of intervention 
was assessed by comparing average of sleep quality score before and after intervention on children with cancer treated by chemotherapy. Sleep quality scoring was conducted before and after intervention for control and intervention groups.

This study conducted in Children Ward-Ground Floor and Children Ward - First Floor in Dr. Kariadi Hospital, Semarang from October - November 2016. Inclusion criteria of this study were children aged 2-18 years with cancer receiving chemotherapy, while the exclusion criteria were children who experienced fever, seizure, asphyxiate, and unconscious. Study subjects who met inclusion criteria then classified into control and intervention groups randomly. This study used block randomization to minimalize possibility of participant number imbalance between both groups.

Minimum number of samples in this study was developed from Sari's study of the effect of progressive muscle relaxation on comfort and nausea of children with cancer receiving chemotherapy in $\mathrm{H}$. Adam Malik Hospital, Medan. In Sari's study, mean difference standard deviation of comfort variable in both groups was 1.36, while the mean difference before and after intervention that was considered clinically significant was 1.33 [28]. In this study, the calculated minimum number of samples per group was 22 participants, thus the total sample was 44 participants. We estimated $10 \%$ of the selected participants could not finish the study thus the corrected total number of samples increased to 49 participants. However, this study could only find 30 respondents that were divided equally into both groups.

Data were collected by pain assessment questionnaire with numeric rating scale, vomiting and nausea was assessed by rhodes index of nausea, vomiting, and retching (Rhodes INVR), PedsQL Multidimensional Fatigue Scale used to assess fatigue, and sleep disturbance was assessed by Pittsburgh Sleep Quality Index (PSQI). Validity test was conducted on 10 respondents in Children Ward - Ground Floor in Dr. Kariadi Hospital, Semarang.

Calculated $r$ value of each question item in Rhodes INVR instrument was (0.808-0.916), while the value for PSQI instrument was (0.759-0.928), and the value for PedsQL Multidimensional Fatigue Scale instrument was $(0.826-0.928)$. Table $r$ value used in this study was 0.532.As calculated $r$ value was larger than table $r$ value; all questions in Rhodes INVR, PSQI, and PedsQL Multidimensional Fatigue Scale were valid. Reliability test was calculated using Cronbach's Alpha test. The results for Rhodes INVR, PSQI, and PedsQL Multidimensional Fatigue Scale were $\alpha=0.967, \alpha=0.978$, and $\alpha=0.984$, respectively. This result proved that all instruments were reliable.

Data analysis was conducted to investigate difference of sleep quality, fatigue, nausea-vomiting scores before and after intervention in both groups, difference of sleep quality, fatigue, and nausea-vomiting scores between both groups after progressive muscle relaxation was performed, and average difference of sleep quality, fatigue, nausea-vomiting scores between both groups after progressive muscle relaxation was performed.

\section{Results}

In the initial stage of this study, 35 children were selected as respondents based on inclusion and exclusion criteria. However, we could not get consent from one child as his parents were resting, thus only 34 children participated in this study. Randomization using random number table with four subjects in each block was performed to allocate 18 respondents to control group and 16 respondents to intervention group. Three respondents from control group and one respondent from intervention group had worsened condition and transferred to ICU. Four respondents were then excluded and the total of 30 respondents were divided equally into two groups. Flowchart of this study is displayed in the following Figure 1.

Average pain score in both groups was obtained from 7-day assessment. Assessment on the $1^{\text {st }}$ day was assumed as zero point (initial point) before progressive muscle relaxation was performed. Pain score in the following days was assessed after progressive muscle relaxation was performed and the

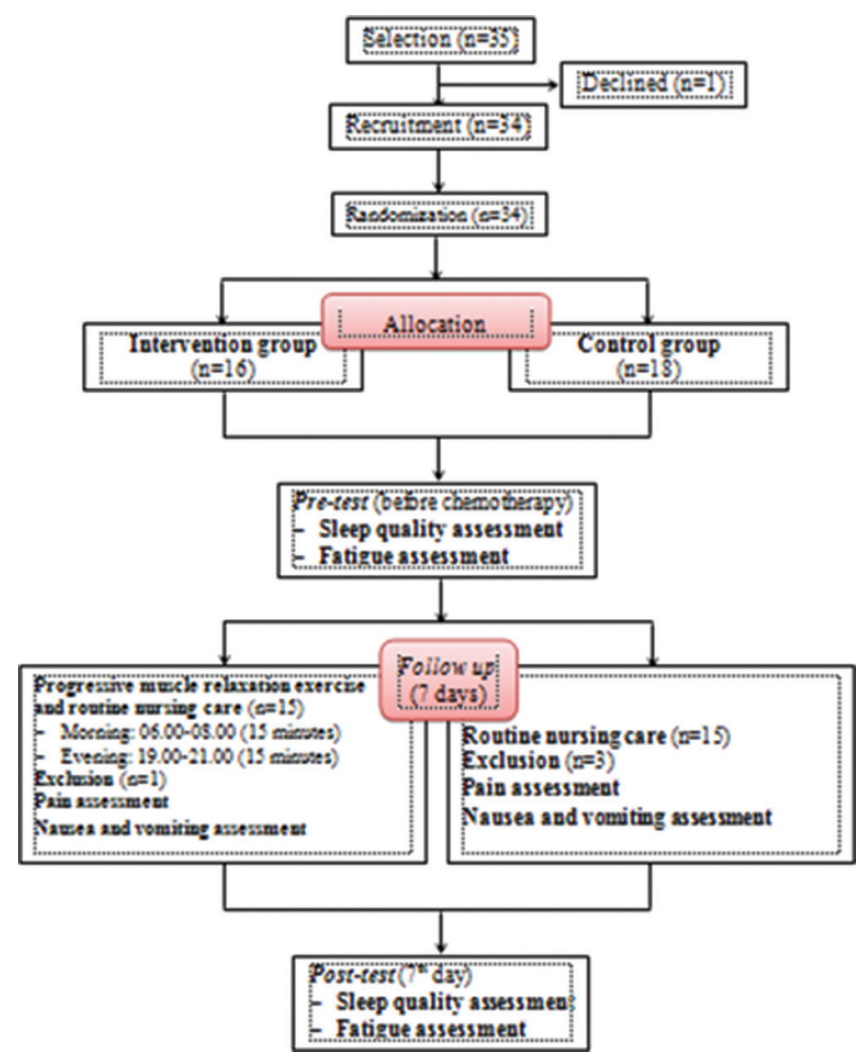

Figure 1: Flow diagram in the study 
assessment of the $7^{\text {th }}$ day was assumed as final point. Figure 2 shows that the average of pain scores in the $1^{\text {st }}$ day was identical for both groups, with the number reached $1.67( \pm 1.67)$ for control group and $1.67( \pm 2.46)$ for intervention group. On the $2^{\text {nd }}$ day, the pain score for intervention group decreased significantly to reach 0.87 $( \pm 1.40)$, yet it increased again on the $3^{\text {rd }}$ day. The score for intervention group was decreasing until the $6^{\text {th }}$ day and slightly increased on the $7^{\text {th }}$ day, with the final score was $0.67( \pm 1.39)$. Meanwhile, the score for control group increased on the $4^{\text {th }}$ day to reach $1.00( \pm 1.30)$ and was decreasing until the final day to reach 0.20 $( \pm 0.56)$. The average pain scores for 7 -day assessment in control and intervention groups were 0.87 and 0.90 , respectively.

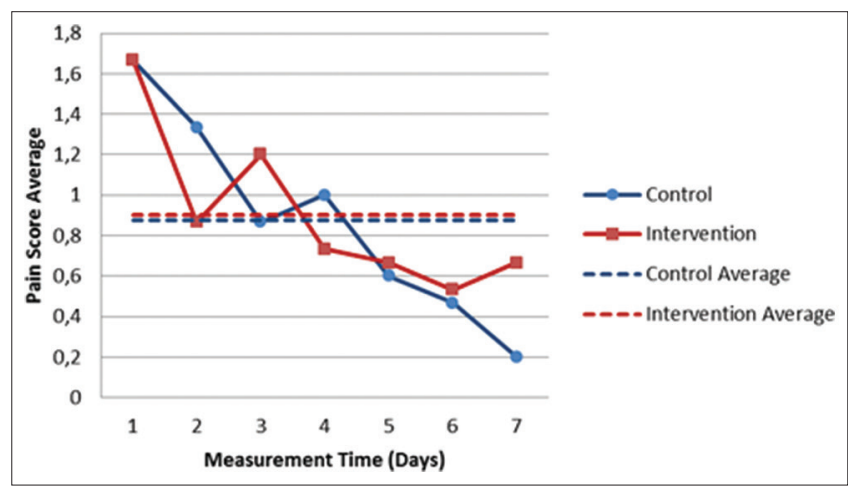

Figure 2: Curve of daily pain score average after progressive muscle relaxation for 7-days

Average nausea-vomiting score in both groups was obtained from 7-day assessment. Assessment on the $1^{\text {st }}$ day was assumed as zero point (initial point) before progressive muscle relaxation was performed. Nausea-vomiting score in the following days was assessed after progressive muscle relaxation was performed and the assessment of the $7^{\text {th }}$ day was assumed as final point. Figure 3 shows that the average of nausea-vomiting scores for intervention group in the $1^{\text {st }}$ day $7.20( \pm 6.88)$ was higher than control group. The scores for both groups were decreasing for the next 3 days, and relatively stable on the $6^{\text {th }}$ day. The score for intervention group increased on the $7^{\text {th }}$ day to reach $0.80( \pm 2.14)$. In contrast, the score for control group

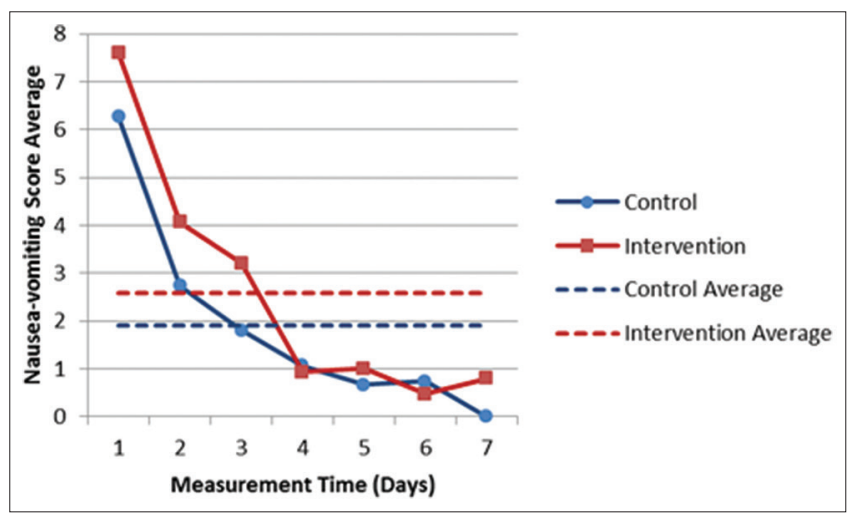

Figure 3: Curve of daily nausea-vomiting score average after progressive muscle relaxation for 7 days continued to decrease on the $7^{\text {th }}$ day to reach 0.00 , which means that respondents on the control group did not experience nausea and vomiting on the final day of assessment. The average nausea-vomiting scores for 7-day assessment in control and intervention groups were 1.89 and 2.58 , respectively.

Table 1 shows the improvement of sleep quality as the scores for both groups were decreased with median for control and intervention groups were 3.00 and 2.00 , respectively. The difference of sleep quality scores in both groups was insignificant with respective $p$ value for control and intervention groups were 0.468 and 0.130 . The median fatigue score for intervention group decreased to reach 76.00 while the score for control group was stable at 78.00. Difference of fatigue scores was insignificant on both groups, where the $p$ values for control and intervention groups were 0.222 and 0.733 , respectively.

Table 1: Scores of sleep quality, fatigue, pain, and nauseavomiting before and after progressive muscle relaxation

\begin{tabular}{|c|c|c|c|c|c|}
\hline Variable & Group & Assessment & Median & Min-max & $p$-value \\
\hline \multirow[t]{4}{*}{ Sleep quality } & \multirow[t]{2}{*}{ Control } & Before & 4.00 & $1-14$ & \multirow[t]{2}{*}{0.468} \\
\hline & & After & 3.00 & $1-15$ & \\
\hline & \multirow[t]{2}{*}{ Intervention } & Before & 3.00 & $1-4$ & \multirow[t]{2}{*}{0.130} \\
\hline & & After & 2.00 & $1-4$ & \\
\hline \multirow[t]{4}{*}{ Fatigue } & \multirow[t]{2}{*}{ Control } & Before & 78.00 & $19-96$ & \multirow[t]{2}{*}{0.222} \\
\hline & & After & 78.00 & $11-100$ & \\
\hline & \multirow[t]{2}{*}{ Intervention } & Before & 82.00 & $47-97$ & \multirow[t]{2}{*}{0.733} \\
\hline & & After & 76.00 & $53-100$ & \\
\hline \multirow[t]{4}{*}{ Pain } & \multirow[t]{2}{*}{ Control } & Before & 2.00 & $0-4$ & \multirow[t]{2}{*}{$0.011^{*}$} \\
\hline & & After & 0.00 & $0-2$ & \\
\hline & \multirow[t]{2}{*}{ Intervention } & Before & 0.00 & $0-8$ & \multirow[t]{2}{*}{$0.042^{*}$} \\
\hline & & After & 0.00 & $0-5$ & \\
\hline \multirow[t]{4}{*}{ Nausea-vomiting } & \multirow[t]{2}{*}{ Control } & Before & 4.00 & $0-20$ & \multirow{2}{*}{$0.005^{*}$} \\
\hline & & After & - & - & \\
\hline & \multirow[t]{2}{*}{ Intervention } & Before & 7.00 & $0-20$ & \multirow[t]{2}{*}{$0.005^{*}$} \\
\hline & & After & 0.00 & $0-7$ & \\
\hline
\end{tabular}

The average pain and nausea-vomiting scores decreased in both groups. Median pain scores for both groups were identical at 0.00 . Difference of pain scores were significant on both groups, where the $p$ values for control and intervention groups were 0.011 and 0.042 , respectively. Median nausea-vomiting scores for both groups were identical at 0.00 . Difference of nauseavomiting scores was significant on both groups, where p-values for control and intervention groups were identical at 0.005 .

Table 2 shows scores of sleep quality, fatigue, pain, and nausea-vomiting for both groups after progressive muscle relaxation. Sleep quality of intervention group was better than control group, with the respective median score of 2.00 compared to 3.00 . Sleep quality score difference between both groups was significant, with $p=0.025$. Median fatigue score in

Table 2: Scores of sleep quality, fatigue, pain, and nauseavomiting before and after progressive muscle relaxation

\begin{tabular}{lllll}
\hline Variable & Group & Median & Min-Max & p-value \\
\hline Sleep Quality & Control & 3.00 & $1-15$ & $0.025^{*}$ \\
& Intervention & 2.00 & $1-4$ & \\
Fatigue & Control & 78.00 & $11-100$ & 0.755 \\
& Intervention & 76.00 & $53-100$ & \\
Pain & Control & 0.00 & $0-2$ & 0.327 \\
& Intervention & 0.00 & $0-5$ & \\
Nausea-vomiting & Control & - & - & 0.150 \\
& Intervention & 0.00 & $0-7$ & \\
\hline${ }^{*}$ Significance at $\alpha$ 0.05. & & & &
\end{tabular}


intervention group was lower than control group, with the number reached 76.00 . This means that the fatigue level of intervention group was higher than control group. Fatigue score difference between both groups was insignificant, with $p=0.755$.

Pain and nausea-vomiting scores were identical for both groups, with median score of 0.00 . Pain and nausea-vomiting scores difference between both groups was insignificant, with $p$ value of pain score and nausea-vomiting score was 0.327 and 0.150 , respectively.

As shown in Table 3, average sleep quality score difference of intervention group $0.53( \pm 1.24)$ was higher than control group $0.33( \pm 1.67)$. Meanwhile, average fatigue score difference of intervention group $2.20( \pm 12.93)$ was higher than control group 1.06 $( \pm 23.19)$. The improvement of fatigue score means that progressive muscle relaxation was able to reduce fatigue level. Average pain score difference of control group $1.46( \pm 1.59)$ was higher than intervention group $1.00( \pm 1.77)$. In contrast, average nauseavomiting score difference of control group $6.26( \pm 6.47)$ was higher than intervention group $6.80( \pm 6.61)$. No average score difference of sleep quality, fatigue, pain, and nausea-vomiting was significant $(p>0.05)$.

Table 3: Average score difference of sleep quality, fatigue, pain, and nausea-vomiting after progressive muscle relaxation

\begin{tabular}{llll}
\hline Variable & Group & Mean $( \pm \mathrm{SD})$ & p-value \\
\hline Sleep Quality & Control & $0.33( \pm 1.67)$ & 0.443 \\
& Intervention & $0.53( \pm 1.24)$ & \\
Fatigue & Control & $1.06( \pm 23.19)$ & 0.430 \\
\multirow{2}{*}{ Pain } & Intervention & $2.20( \pm 12.93)$ & \\
& Control & $1.46( \pm 1.59)$ & 0.290 \\
Nausea-vomiting & Intervention & $1.00( \pm 1.77)$ & \\
& Control & $6.26( \pm 6.47)$ & 0.916 \\
& Intervention & $6.80( \pm 6.61)$ & \\
\hline
\end{tabular}

\section{Discussion}

Sleep disturbance in children influenced by biological mechanism where the increase of interleukin (IL)-6 and tumor necrosis factor (TNF)- $\alpha$ reduce total sleep duration during the night and less sleep during the day [29]. IL-6 and TNF- $\alpha$ are essential cytokines as sleep management substances that increase in children suffered from obstructive sleep apnea, sleep insufficiency, and excessive drowsiness during the day. Changes in children sleep pattern caused by high level of dexamethasone treatment affect HPA and change of cytokines. Corticosteroid increases alertness and disturbs release of corticotrophin releasing hormone $(\mathrm{CRH}) . \mathrm{CRH}$ activates norepinephrine system that causes awake condition and slow-wave sleep [30]. Common sleep problems include difficulty to sleep, increased frequency of waking up in the middle of the night, and excessive drowsiness during the day [17].
Dexamethasone is a drug that affects sleep pattern [31]. Dexamethasone increases sleep duration and reduces frequency of waking up during the night, improves sleep efficiency, and more sleep during the day [32]. Other effects of dexamethasone are causing fatigue, irritated, insomnia, hypersomnia, mood swing, psychosis, and even consciousness fluctuation. Dexamethasone is given the induction, consolidation, and maintenance phases with dose of $6-12 \mathrm{mg} / \mathrm{m}^{2} /$ day. Dexamethasone is given for $2-3$ years of total chemotherapy program [30].

This study results show that there was no relation of medicine to sleep quality. This contradicts other studies results which concluded that dexamethasone affected children's sleep [30], [32], [33], [34]. Study of pharmacokinetic mechanism of dexamethasone in induction phase also stated that sleep disturbance was experienced by children treated with dexamethasone. However, this study explains that pharmacokinetically, dexamethasone clearance of children is higher than adult [35]. Sleep duration improvement occurred during the day and evening in 5 days of consuming dexamethasone. This improvement returned to normal after dexamethasone was not consumed from the $16^{\text {th }}$ to $15^{\text {th }}$ days (washout period) and continued for the next 13 days [30].

Age is regarded as one of influencing factors of children sleep pattern [16], [36]. Yet, in our study, age did not related to sleep quality. In average, children in this study were in school age (6-12 years old) [37]. These children has varying sleep requirement based on their age, with children aged 6 years need $11-12 \mathrm{~h}$ of sleep in the evening while the ones aged 11 years require 9-10 h. However, children in school age often reject to sleep early as they start to feel freedom and do not care of their fatigue [38].

Some studies suggested children's sleep influenced by gender [16], [36]. However, the results of our study contradict this finding. Combs et al. found that children's sleep duration and schedule influenced by their age, body mass index, and ethnicity, not by their gender, family income, and parents' education background [34]. Short duration of sleep affects health status as it causes hypertension and obesity in children due to disturbance in metabolic regulation. This change also causes mood swing, depression, emotional change, and concentration problems, which affects decreased achievements in school and higher possibility of traffic accidents for adolescent [11], [39].

Sleep quality in this study had no relation with medical diagnose or children's type of cancer. Brain tumor is one type of cancer that influences sleep disturbance [16]. Since it causes dysfunction in hypothalamus; the sleep-wake management center. Decreased neuroendocrine level increases hormones fluctuation that causes sleep disturbance such as excessive drowsiness during the day [20]. Other brain injuries such as hydrocephalus, brain surgery 
procedures, and cranial radiation therapy also cause sleep disturbance [9].

The result showed that progressive muscle relaxation had statistical significance to sleep quality, where there was a sleep quality improvement in children treated with progressive muscle relaxation. However, this result contradicted with Zupanec et al. study, where they found that progressive muscle relaxation had no statistical significance to sleep quality of children with ALL, even though there was an increased sleep duration and reduced frequency of waking up during the night. Based on our result, it can be concluded that progressive muscle relaxation had clinical benefit for children receiving chemotherapy [40].

Fatigue is an exhausted condition influenced by anemia, drugs, nausea-vomiting, metabolism disorder, hormone deficiency, pain, or infection. Anemia is a decreased number of red blood cells, which causes fatigue. The essential part of a red blood cell is hemoglobin; the low level of hemoglobin creates lack of oxygen supplied to other cells and subsequently inhibits many activities [41]. Our results showed that age, gender, medical diagnoses, and drugs had no significant relation to fatigue after progressive muscle relaxation, yet fatigue was related to chemotherapy stage. This result is in line with Utami's study that concluded age, gender, cancer type, chemotherapy type, and nutritional status have no significant relation on fatigue level of children receiving chemotherapy [42].

Nunes, Jacob, Adlard, Sekola, and Nascimento published different results where they found that age, gender, and medical diagnose were related to sleep and fatigue on children and adolescent with cancer in home care. Children and adolescent with cancer were more often experienced sleep disturbance or fatigue than general and cognitive fatigue. Their study found that adolescent experienced more fatigue than children, as age difference affects hormonal change in puberty, more social involvement, and increased anxiety, which, in turns, affects fatigue level [43].

Our result also showed there was no significant relation of progressive muscle relaxation in children with cancer to their fatigue level, yet there was an increased fatigue score which proved that there was a decreased fatigue level. This result is supported by Zupanec et al. study, where they found that sleep hygiene and relaxation had no statistical significance on fatigue, even though there was fatigue level change after intervention [40].

Kaushal et al. had different result where progressive muscle relaxation was more effective than aerobic exercises performed \pm 20 min in 3 -week intervention [41]. Allenidekania and Sari supported this result as they found that progressive muscle relaxation was effective for reducing fatigue level of hospitalized children with cancer receiving chemotherapy [44]. This contradicting results are influenced by difference stage of chemotherapy, as there are difference regiments experienced by children, which affect their fatigue level. This analysis is supported by Yeh et al. study of the relation of clinical factors (hemoglobin level, chemotherapy agent, and corticosteroid use) on fatigue before and after 10-day chemotherapy for children with cancer. Their study states that children experienced fatigue on the first few days of chemotherapy cycle. The use of corticosteroid and hemoglobin level had significant relation to increased fatigue level after several days of chemotherapy, where the highest level was experienced on the $5^{\text {th }}$ day of corticosteroid treatment [45].

Fatigue and sleep quality are related. Sleep disturbance during the night is one of the essential factors causing fatigue. Fatigue in turns causes drowsiness and the increased frequency of sleep during the day, which subsequently leads to sleep disturbance during the night due to fragmented sleepwake cycle [46]. Nurses need to review the effect of fatigue on children quality of life. Nurses could performed energy management by reviewing children fatigue level, their cardio respiration response on activity (tachycardia, hemodynamic pressure, and breathing frequency), occurrence of pain, nutrition intake, and taking note of children sleep pattern and schedule.

Pain experienced by children with cancer caused by infiltration of cancer cell to other organs or tissues. Chemotherapy or radiation also causes pain due to mucositis, abdominal and anal pain caused by intestinal neuropathy as a result of vinca alkaloid therapy, esophageal pain increased gastric acid caused by high dose of corticosteroid, and spinal pain. Pain also experienced during lumbar puncture, bone marrow aspiration, and central venous catheter insertion. Pain affects an individual ability to reach deep sleep due to increased frequency of waking up, threat of repetitive pain, and alertness of more severe pain [46]

Neurological experience influences children perception on pain. Environmental and psychological factors are also significant in children perception on pain. Other factors such as age, genders, cognitive level, temperament, previous pain experience, and family and cultural background are unalterable [12]. Situational factors that can be modified are behavioral, cognitive, and emotional factors. These factors varied based on situation such as children knowledge of pain, pain treatment, and children and parents feeling on experienced pain. Children have limited pain experience, thus these situational factors have more effect on them than adults [2]

Progressive muscle relaxation in children with cancer had significant relation to pain. Metaanalysis conducted by Christaki and Yfandopoulou found that progressive muscle relaxation in children and adolescent decrease chronic abdominal pain. Progressive muscle relaxation is one of complementary 
therapies that have been proven to be able to reduce stress and pain. Exercises in progressive muscle relaxation are simple, non-invasive, and easy to teach and perform anywhere anytime. Nurses play a major role in reviewing and managing pain in children with cancer. Proper pain review requires proper pain assessment tools. Comprehensive pain review includes location, characteristic, quality, duration, severity, and precipitation factor. Nurses also need to observe non-verbal pain signs. Non-pharmacological pain management could be taught by identifying relaxation technique in accordance with children ability [47].

Potential stimulating condition of anticipative nausea-vomiting is seeing and experiencing unique aroma of hospital, nurses, ward, or other things related with hospital. Children experienced this condition repeatedly thus generating manual response of anticipative nausea that has been felt even before chemotherapy. Anticipative nausea-vomiting level and severity tend to increase after repetitive chemotherapy cycle. Acute nausea-vomiting is the nausea-vomiting that occur during $24 \mathrm{~h}$ period after chemotherapy, while slow nausea-vomiting occur 1-7 days after chemotherapy.

Our results showed that progressive muscle relaxation in children with cancer had significant relation to nausea-vomiting. Sari's study of effect of progressive muscle relaxation on comfort, nauseavomiting in children receiving chemotherapy in $\mathrm{H}$. Adam Malik Hospital, Medan supports this result. This study used quasi-experiment pre-post-test with control group. Samples were collected consecutively, yielded in 21 respondents per group. This study found that progressive muscle relaxation improved comfort and reduced nausea-vomiting in children receiving chemotherapy [28].

\section{Conclusion}

Sleep quality and fatigue before and after progressive muscle relaxation had no significant difference in control and intervention groups, while pain and nausea-vomiting had significant difference in both groups before and after progressive muscle relaxation. The effect of progressive muscle relaxation on fatigue, pain, and nausea-vomiting showed no significant relation in control and intervention group, yet sleep quality had significant relation in both groups after progressive muscle relaxation. Difference of sleep quality, fatigue, and pain, and nausea-vomiting before and after progressive muscle relaxation showed no significant difference between control and intervention groups.

\section{Acknowledgments}

I would like to thank Dr. Allenidekania, S.Kp., M.Sc., the study respondents and their parents, and the Head of the Room Dr. Kariadi Hospital, Semarang.

\section{References}

1. Kementerian Kesehatan RI. Buku Saku Penemuan Din Kanker Pada Anak. Jakarta: Direktorat Jenderal Pencegahan dan Pengendalian Penyakit Tidak Menular; 2016. https://doi. org/10.22236/jmbp.v1i1.5708

2. Carman S, Kyle T. Essentials of Pediatric Nursing. $2^{\text {nd }}$ ed. Philadelphia, AP: Lippincott Williams and Wilkins; 2013.

3. Ball JW, Bindler Ruth C, Cowen Kay J. Principles of Pediatric Nursing: Caring for Children. $5^{\text {th }}$ ed. New Jersey: Pearson Education Inc.; 2012.

4. Marcdante K, Kliegman RM, Behrman RE. Nelson: Essentials of Pediatric. $6^{\text {th }}$ ed. Philadelphia, PA: Saunders Elsevier; 2014.

5. National Cancer Institute. Definition of Cancer, a Brief Explanation of the Origins of Cancer in Cells, Basic Cancer Statistics, and Links to other $\mathrm{NCl}$ Cancer-related Resources. National Cancer Institute; 2015. Available from: http://www. cancer.gov/about-cancer/what-is-cancer. [Last access on 2017 May 22]. https://doi.org/10.1093/jnci/79.3.610-a

6. World Health Organization. Global Status Report on Noncommunicable Diseases 2014: Attaining the Nine Global Noncommunicable Diseases Targets; a Shared Responsibility. Geneva: World Health Organization; 2014. Available from: http://www.who.int. [Last access on 2017 Jul 01].

7. Nicki LP, Barbara LM. Pediatric Nursing: Caring for Children and Their Families. $3^{\text {th }}$ ed. Delmar: Cengage Learning; 2012.

8. Nancy EK. The Pediatric Chemotherapy and Biotherapy Curriculum. $3^{\text {rd }}$ ed. United States of America: APHON; 2011.

9. Walter LM, Nixon GM, Davey MJ, Downie PA, Horne RS. Sleep and fatigue in pediatric oncology: A review of the literature. Sleep Med Rev. 2015;24:71-82. https://doi.org/10.1016/j. smrv.2015.01.001 PMid:25679070

10. McCulloch R, Hemsley J, Kelly P. Symptom management during chemotherapy. Pediatr Child Heal. 2013;24(4):166-71.

11. Erickson JM. Approaches to measure sleep wake disturbances in adolescents with cancer. J Pediatr Nurs. 2009;24(4):255-69. PMid:19632503

12. Kwekkeboom KL, Abbott-Anderson K, Cherwin C, Roiland R, Serlin RC, Ward SE. Pilot randomized controlled trial of a patient-controlled cognitive-behavioral intervention for the pain, fatigue, and sleep disturbance symptom cluster in cancer. J Pain Symptom Manage. 2012;44(6):810-22. https://doi. org/10.1016/j.jpainsymman.2011.12.281

PMid:22771125

13. van Litsenburg RR, Huisman J, Hoogerbrugge PM, Egeler RM, Kaspers GJ, Gemke RJ. Impaired sleep affects quality of life in children during maintenance treatment for acute lymphoblastic leukemia: An exploratory study. Health Qual Life Outcomes. 2011;9(1):25. https://doi.org/10.1186/1477-7525-9-25 PMid:21496357

14. Buffum D, Koetters T, Cho M, Macera L, Paul SM, West C, et al. The effects of pain, gender, and age on sleep/wake and circadian rhythm parameters in oncology patients at the initiation 
of radiation therapy. J Pain. 2011;12(3):390-400. https://doi. org/10.1016/j.jpain.2010.09.008

\section{PMid:21146465}

15. Walker AJ, Pongsing Y, Nail L, Pedhiwala N, Leo M, Price J, et al. Sleep wake patterns of school-age children and adolescents before diagnosis and during induction chemotherapy for acute lymphocytic leukemia. J Pediatr Nurs. 2011;26(6):e37-44. https://doi.org/10.1016/j.pedn.2011.02.006 PMid:22055382

16. Kaleyias J, Manley P. Sleep disorders in children with cancer. YSPEN. 2012;19(1):25-34. PMid:22641073

17. Rahmawaty F, Allenidekania, Waluyanti F. Masalah Tidur dan Kelelahan Pada Remaja Pengidap Kanker Yang Mendapatkan Kemoterapi. Indonesia: Universitas Indonesia; 2013.

18. Sahin ZA, Dayapoglu N. Effect of progressive relaxation exercises on fatigue and sleep quality in patients with chronic obstructive lung disease (COPD). Complement Ther Clin Pract. 2015;21(4):277-81. https://doi.org/10.1016/j.ctcp.2016.05.013 PMid:26573455

19. Cohen R, Halevy A, Shuper A. Children's sleep disturbance scale in differentiating neurological disorders. Pediatr Neurol. 2013;49(6):465-8. https://doi.org/10.1016/j. pediatrneurol.2013.06.010

PMid:24080271

20. Gapstur R, Gross CR, Ness K. Factors associated with sleepwake disturbances in child and adult survivors of pediatric brain tumors: A review. Oncol Nurs Forum. 2009;36(6):723-31. https:// doi.org/10.1188/09.onf.723-731

PMid: 19887361

21. Sadeh A. Cognitive behavioral treatment for childhood sleep disorders. Clin Psychol Rev. 2005;25(5):612-28.

PMid:15979219

22. Kanitz JL, Camus ME, Seifert G. Keeping the balance an overview of mind-body therapies in pediatric oncology. Complement Ther Med. 2013;21(Suppl 1):S20-5. https://doi. org/10.1016/j.ctim.2012.02.001

PMid:23578913

23. Srilekha S, Soumendra S, Chattopadhyay PK. Effect of muscle relaxation trainning as a function of improvement in attentiveness in children. Proc Soc Behav Sci. 2013;91:606-13. https://doi.org/10.1016/j.sbspro.2013.08.460

24. Lee E, Bhattacharya J, Sohn C, Verres R. Monochord sounds and progressive muscle relaxation reduce anxiety and improve relaxation during chemotherapy: A pilot EEG study. Complement Ther Med. 2012;20(6):409-16. https://doi.org/10.1016/j. ctim.2012.07.002

PMid:23131371

25. Charalambous A, Giannakopoulou M, Bozas E, Paikousi L. A randomized controlled trial for the effectiveness of progressive muscle relaxation and guided imagery as anxiety reducing interventions in breast and prostate cancer patients undergoing chemotherapy. Evid Based Complement Alternat Med. 2015;2015:270876. https://doi.org/10.1155/2015/270876 PMid:26347018

26. Sastroasmoro S, Ismael S. Dasar-dasar Metodologi Penelitian Klinis. $5^{\text {th }}$ ed. Jakarta: Sagung Seto; 2010.

27. Dahlan MS. Membaca dan Menelaah Jurnal Uji Klinis. Jakarta: Salemba Medika; 2010.

28. Sari R. Pengaruh Relaksasi otot Progresif Terhadap Kenyamanan, Mual dan Muntah Akibat Kemoterapi Pada Pasien Kanker Anak di RSUP H. Adam Malik Medan. Indonesia: Universitas Indonesia; 2013. https://doi.org/10.32734/tm.v1i1.33

29. Vallance K, Yang J, Li J, Crabtree VM, Hinds PS, Mandrell BN.
Disturbed sleep in pediatric patients with leukemia: The potential role of interleukin-6 (-174GC) and tumor necrosis factor (-308GA) polymorphism. Oncol Nurs Forum. 2011;38(5):E36572. https://doi.org/10.1188/11.onf.e365-e372 PMid:21875833

30. Rosen G, Harris AK, Liu M, Dreyfus J, Krueger J, Messinger YH. The effects of dexamethasone on sleep in young children with acute lymphoblastic leukemia. Sleep Med. 2015;16(4):503-9. https://doi.org/10.1016/j.sleep.2014.11.002 PMid:25799940

31. Daniel LC, Li Y, Kloss JD, Reilly AF, Barakat LP. The impact of dexamethasone and prednisone on sleep in children with acute lymphoblastic leukemia. Support Care Cancer. 2016;24(9):3897906. https://doi.org/10.1007/s00520-016-3234-y

PMid:27108263

32. Hinds P, Hockenberry M, Srivastava DK, Gattuso J, Jones H, West $\mathrm{N}$, et al. Sleep, fatigue, and dexamethasone in children and adolescents with acute lymphocytic leukemia. Oncol Nurs Forum. 2007;34(1):197-8.

33. Rogers VE, Ancoli-Israel S, Hinds PS. Impairment in circadian activity rhythms occurs during dexamethasone therapy in children with leukemia. Pediatr Blood Cancer. 2014;61(11):198691. https://doi.org/10.1002/pbc.25147

PMid:25066691

34. Combs D, Goodwin JL, Quan SF, Morgan WJ. Longitudina differences in sleep duration in hispanic and Caucasian children. Sleep Med. 2016;18:61-6. https://doi.org/10.1016/j. sleep.2015.06.008

PMid:26299467

35. Vallance K, Liu W, Mandrell BN, Panetta JC, Gattuso JS, Hockenberry $\mathrm{M}$, et al. Mechanisms of dexamethasone-induced disturbed sleep and fatigue in paediatric patients receiving treatment for ALL. Eur J Cancer. 2010;46(10):1848-55. https:// doi.org/10.1016/j.ejca.2010.03.026

PMid:20400291

36. Hockenberry MJ, Hooke MC, Gregurich M, Mccarthy K, Sambuco G, Krull K. Symptom clusters in children and adolescents receiving cisplatin, doxorubicin, or ifosfamide. 2010;37(1):E16-27. https://doi.org/10.1188/10.onf.e16-e27 PMid:20044328

37. Wong DL, Hockenberry M, Wilson D, Winkelstein ML, Schwartz P. Buku Ajar Keperawatan Pediatrik. $6^{\text {th }}$ ed. Jakarta: EGC; 2009.

38. Potter PA, Perry A. Fundamental of Nursing. $7^{\text {th }}$ ed. Singapore: Elsevier; 2010.

39. Kozier B, Erb G, Berman A, Snyder S. Buku Ajar Fundamental Keperawatan: Konsep, Proses, and Praktik. Jakarta: EGC; 2010.

40. Zupanec S, Jones H, Mcrae L, Weston J. A sleep hygiene and relaxation intervention for children with acute lymphoblastic leukemia. Cancer Nurs. 2017;40(6):488-96. https://doi. org/10.1097/ncc.0000000000000457

PMid:27922922

41. Kaushal DB, Narendra BD, Smitha D. A comparative study between relaxation technique and aerobic exercise in fatigue during chemotherapy in acute lymphoblastic leukemia in children. Indian J Physiother Occup Ther. 2013;7(3):140-5. https://doi.org/10.5958/j.0973-5674.7.3.081

42. Utami A. Faktor-faktor Yang Mempengaruhi Kelelahan Pada Anak Dengan Kanker. Indonesia: Universitas Indonesia; 2016.

43. Nunes MD, Jacob E, Adlard K, Secola R, Nascimento L. Fatigue and sleep experiences at home in children and adolescents with cancer. Oncol Nurs Forum. 2015;42(5):498-506. https://doi. org/10.1188/15.onf.498-506

PMid:26302278 
44. Allenidekania, Sari R. The Effectiveness of Exercise: Progressive Muscle Relaxation (PMR) to Reduce Cancer Related Fatigue in Children Receiving Chemotherapy at RS Adam Malik, Medan. Bali: International Nursing Conference; 2013.

45. Yeh $\mathrm{CH}$, Chiang YC, Lin L, Yang CP, Chien LC, Weaver MA et al. Clinical factors associated with fatigue over time in paediatric oncology patients receiving chemotherapy. $\mathrm{Br} J$ Cancer. 2008;99(1):23-9. https://doi.org/10.1038/sj.bjc.6604434
PMid: 18577992

46. Duff VG, Lee KA, Nail LM, Nicholson S, Johnson K. Pain, sleepdisturbance, and fatiguein children with leukemia and their parents: A pilot study. Oncol Nurs Forum. 2006;33(3):641-6. PMid:16676020

47. Christaki M, Yfandopoulou P. Progressive muscle relaxation as treatment option for children/adolescents with functional gastrointestinal disorders. Health Sci J. 2014;8:187-92. 